\title{
THE MAKING OF THE GDAŃSK METROPOLITAN REGION. LOCAL DISCOURSES OF IDENTITIES, POWERS, AND HOPES
}

\author{
MARIUSZ CZEPCZYŃSKI \\ Spatial Management Department, Institute of Geography, University of Gdańsk, Poland \\ Manuscript received: February 3, 2014 \\ Revised version: June 5, 2014
}

\begin{abstract}
CZEPCZYŃSKI M., 2014. The making of the Gdańsk metropolitan region. Local discourses of powers, identities and hopes. Quaestiones Geographicae 33(4), Bogucki Wydawnictwo Naukowe, Poznań, pp. 57-66. DOI 10.2478/quageo-2014-0049, ISSN 0137-477X.

AвSTRACT: The process of metropolitanisation of the Gdańsk area is facilitated by public discourse involving local and regional politicians, media, and inhabitants. The discussion is based upon historical narrations, but also local ambitions, hopes and emotions, as well as infrastructural projects and investment attractiveness. Foucault suggests that modern power is a dispersed set of micro-practices, many of which operate through the normalising gaze of surveillance regimes. Gdańsk metropolitan cooperation, competition and encounters make the core of the paper; local and regional unifying initiatives and processes are accompanied by examples of separatism, identity conflicts, and political disagreements.
\end{abstract}

KEY WORDS: metropolitan region, Gdańsk, cooperation, competition

Mariusz Czepczyński, Spatial Management Department, Institute of Geography, University of Gdańsk, ul. Bażyńskiego 4, 80952 Gdańsk, Poland; e-mail: geomc@ug.edu.pl

\section{Introduction}

There are three main approaches towards metropolitan cooperation. The thesis is based on administrative, top-down decisions, often used in stronger social systems. The antithesis is total disintegration and internal competitiveness, typical of liberal systems. The synthesis - joint action of both; the most efficient and sustainable (Judge et al. 2005). Metropolitan growth is based on compromises, coalitions and negotiations to make the best of combined connections and mobility, cooperation and competition, flexibility and dynamism, while keeping identities and internal diversity. Metropolitan cooperation can be interpreted as a process facilitated by various actors, both internal and external, placed between integration and cooperation, and between fears and ambitions of numerous actors on the local, regional and national scenes. Regional urban cooperation is based on combined benefits and economic, social, and cultural value-added synergies. Cooperation is not always easy, but the development goal is often one: a better future - living, education, labour, infrastructure, culture, increasing competitiveness and attractiveness at the regional, national and European levels. However, governmental initiatives, like proposals of a new urban policy, show some 'metropolitan fear' - ignoring the fact of the rapid development of metropolitan zones and inter-metropolitan cooperation, and delaying any legal solutions to regulate metropolitan cooperation.

Traditionally, metropolitan regions can be perceived as large production and consumption 
systems based upon extensive information and knowledge processing. They are usually characterised by an "agglomeration of economic activities and by their intra-regional transport infrastructure, facilitating very large movements of people, inputs and products within interaction borders" (Klaesson et al. 2013: 1). Metropolitan regions are large and multi-centred agglomerations of economies and societies in the form of a vast urbanised region characterised by a large integrated labour market, with a much more intensive commuting and search for jobs and workforce within the region than between regions (Johansson 1997). More recently, their function as gateways to other regions has been stressed, thus linking economic actors in the region with those in other regions nationally and abroad (Andersson 2000).

The main aim of this paper is to investigate the level of metropolitanisation of the Gdańsk region in Poland, to analyse its metropolitan character, and its anti-metropolitan features. The discursive process of cooperation and competition within the Gdańsk metropolitan area, analysed here in terms of the antithesis and the synthesis, is a major development issue for the region and its future. The deconstruction of processes, actors and actions responsible for major metropolitan features, its internal agglomeration and linkages with external actors, together with the unification and disintegration of the Gdańsk metropolis can be seen as a diagnosis of the on-going process.

\section{The Gdańsk urban region in transition}

Regional and especially intra-urban cooperation is a complex and learning process facilitated by various local and regional actors. Different conditions, goals, expectations and ambitions create a distinctive network of hopes, threats and opportunities which shape the future of a region. Ruling out the upcoming prospect of virtually and legally disjointed regions depends on the ability of local communities and elites to overcome mental and imagined barriers, and take advantage of possible forms of collaboration. A dynamic expansion of a large urban region is often viewed as a regional an- swer to global competition between locations. In recent years, cities and regions have begun to behave much like enterprises, competing for investment and negotiating their places in multi-national, but sometimes also inter-regional networks of globalised prosperity (Herrschel, Newman 2005).

A vast majority of urban regions are monocentric, built around a dominant functional and administrative hub. The other type - polycentric structures - have grown with the rise of automobile and rail transport, and comprise a number of cities, towns, and other urban areas that, through population growth and physical expansion, have merged to form one, more or less continuous, urban and economically developed area (Knox, Pinch 2006). An urban polycentric system, known in America as a 'metroplex', is a contiguous metropolitan area that has more than one principal anchor city of near-equal importance. It is this 'near-equal' importance, specialisation and distribution of major functions that makes regions polycentric.

The Tri-City name of the agglomeration of Gdańsk, Gdynia and Sopot places a different gloss on the term 'multi-polar' (or multi-centric, or polycentric), and makes the Gdańsk area somewhat unique in terms of general classifications of multi-polar agglomerations. Davoudi (2005: 2) says: "At the inter-urban scale, the focus is on the polycentric urban region with three or more cities that are historically and politically separate, have no hierarchical ranking, are in reasonable proximity to each other, and demonstrate a high degree of functional interconnections and complementarities".

The Gdańsk area meets two of these conditions, but fails on the remaining two. Much of the agglomeration's development has been shaped by lack of interconnection and complementarity between its main parts, and Gdańsk as a regional capital is evidently ranked higher than Gdynia. This arose out of tensions which still underlie much of the discussion of integration and policies in the city region (Judge et al. 2005). Administrative divisions and borders create virtual regions, while independent local municipalities and authorities make for dispersed powers and decision-making processes, control and responsibilities. 
This biggest agglomeration on the southern Baltic coast consists of the cities of Gdańsk and Gdynia, the resort city of Sopot between them, plus the surrounding belt of suburbs and satellite towns - altogether a population of about 1.2 million. It is located at the mouth of the Vistula River, about $350 \mathrm{~km}$ northwest of Warsaw. The Gdańsk, or Tri-City ${ }^{1}$, agglomeration is Poland's third largest urban centre, and acts as the primary economic, social, cultural, educational, transport and political focus of the northern part of the country. The functional Tri-City agglomeration consists of at least 13 urban municipalities and 27 rural communes ${ }^{2}$ covering more than 2,000 sq. km, including Gdańsk $(460,000)$, Gdynia $(248,000)$, Tczew $(59,000)$, Wejherowo $(50,000)$, Rumia $(47,000)$, and Sopot $(38,000)$. The spatial development of the agglomeration is concentrated along the main and dominant transport corridor linking the main centres, going from Tczew in the south, via Gdańsk, Sopot and Gdynia, to Wejherowo in the north-west (ca. $70 \mathrm{~km}$ ). The core of the metropolis extends along a 20-km axis from Gdańsk through Sopot to Gdynia. A vast majority of key local and regional central functions are concentrated along this axis, together with the main centres of the conurbation: Gdańsk Centre, Gdańsk Wrzeszcz and Gdynia Centre (Judge et al. 2005). The creation of a polycentric agglomeration has been enhanced by natural conditions and the linear historical development of Gdańsk, facilitated by the narrow coastal strip of land between the beach and the edge of morainic hills.

The past development and present structure of the conurbation is deeply embodied in local history. While Gdańsk is an ancient port city and Sopot was a fashionable nineteenth century seaside resort patronised mainly by Germans and

\footnotetext{
Tri-City, or Trójmiasto in Polish, sometimes spelled as 3miasto/3city, is a commonly known, though unofficial, name in Poland. For the first time it came as a legal name in the Tri-City Landscape Park (Trójmiejski Park Krajobrazowy) in 1979. The term comes from the number of major municipalities: Gdańsk, Gdynia and Sopot. It is broadly used in national media, including weather maps, news, and others.

2 There are many functional and planning delimitations of the Gdańsk Metropolitan Area. The population of the functional urban area varies, depending on the estimation, from 750,000 to 1.3 million.
}

Poles, Gdynia was an artificial creation arising out of the 1919 Versailles Treaty. After the Treaty, the historic city and port of Gdańsk (Danzig) was given a more independent status from Germany as a Free City to allow Poland access to the Baltic Sea. Nevertheless, in 1926, the Poles decided to build their own Baltic port in the village of Gdynia, some $20 \mathrm{~km}$ north of Gdańsk. From the very beginning Gdynia was constructed as a Polish competitor to the German Gdańsk/Danzig. The new town expanded quickly to 130,000 inhabitants in 1939. During the Second World War, the Polish Corridor, including Gdynia ${ }^{3}$, and the Free City of Gdańsk were incorporated into the German Reich, and thus under the control of one regional administration. A common public transport system was established to serve the entire area (Czepczyński 2009).

The communist era brought enforced amalgamation based on a top-down approach. The transport system, port authorities, together with all vital economic, social and cultural functions, were integrated within the central and regional planning projects. After the political shifts of 1989, the municipalities became more independent and followed different development paths based on their path dependency. In 1999, a new administrative system was implemented: Gdańsk was designated the capital of Pomerania voivodeship (NUTS-2 unit), while all three main urban municipalities, Gdańsk, Gdynia and Sopot, became independent unitary authorities combining local and low-level regional (poviat, NUTS-4 unit) functions. The Gdańsk area holds most of the vital economic and social activities of the whole region. Since the 1970s, the local community has been considered active, open-minded, anti-totalitarian, and liberal. This, together with the legacy of 'the cradle of Solidarity', has contributed to a strong localism. In addition, the regional economy has not been driven by strong foreign investment, and is instead largely the outcome of an effective combination of local cooperation and competition.

During the Second World War Gdynia was renamed Gotenhafen and turned into a major base on the Baltic. 


\section{The bonding role of the transport network}

As in other European cities, public transport in Gdańsk developed since the late $19^{\text {th }}$ century into an extensive tram system, extended to Sopot in 1945, while trolleybuses were introduced in Gdynia, or Gotenhafen, in 1943. The making of a unified metropolitan region began in October 1950 with the decision to build a separate railway lane for urban transport. A new improved rail connection was more than necessary to link the practically destroyed Gdańsk centre with residential districts in the northern parts of the urban region. On 22 July 1952, a two-track connection from the Gdańsk Main Station to Gdynia Orłowo was ready; in 1954 dual-track traffic reached the Gdynia Główna station. The completion of an electrified Rapid Urban Rail (Szybka Kolej Miejska, or SKM) system between Gdańsk and Gdynia accelerated the agglomeration's integration. This major Polish urban train system accounts for ca. $19 \%$ of all Tri-City traffic and transports ca. 35.2 million passengers per year ${ }^{4}$ - more than 100,000 passengers daily. The trains operate now at 7- (rush hours) and 15-minute intervals between Gdańsk and Gdynia, with an hourly night service. Currently, the SKM is a limited company owned by the Polish State Railways (47.8\% of shares), the Ministry of Treasure (22.6\%), Pomeranian voivodeship (12.8\%), the City of Gdańsk (9.6\%), the City of Sopot (2.8\%), the City of Gdynia $(2.6 \%)$, and the Urban Communes of Pruszcz Gdański (1.6\%) and Rumia (0.2\%). Some of the municipalities, like Gdańsk, are interested in more shares and an active role in managing and planning further operations, while others, like Gdynia, take a more passive part in SKM development.

Since the late 1960s, the process of planned regional development of Gdańsk voivodeship has contributed to extensive industrial and residential suburbanisation of the existing urban centres, thus furthering their functional and physical inte-

4 In 2013 it was ca. 2 million less than in 2012 due to an extensive reconstruction of the tracks and stations (Weltrowski 2014). The peak of popularity was reached in the late 1970s, when the yearly number of SKM passengers exceeded 100 million. gration along the main transport artery as a spine of the agglomeration. The backbone of the TriCity is the inner highway between Gdańsk (Zwycięstwa - Grunwaldzka), Sopot (Niepodłegłości) and Gdynia (Zwycięstwa Avenue). It consists of 2-4 lanes in each direction. In 1975 a $40 \mathrm{~km}$ dual carriageway Tri-City Ring $\operatorname{Road}^{5}$ (Obwodnica Trójmiejska) was constructed. It starts in the vicinity of Pruszcz Gdański and goes through the western districts of Gdańsk to Gdynia-Chylonia. During the 1970s an active and a passive policy of de-agglomeration was implemented when a number of important industrial plants and large housing estates had been located in the outer zone of the agglomeration, but mostly along the transport axis, notably in Pruszcz and Rumia (Czepczyński 2005). Nevertheless, the cities of the agglomeration developed largely autonomously, keeping their own distinct identities.

An important step in transport integration was the decision to construct a second line of the suburban railway known as the Pomeranian Metropolitan Rail (Pomorska Kolej Metropolitalna, or PKM). In January 2008 the municipalities of Gdańsk and Gdynia, together with the voivodeship self-government, decided to apply jointly for EU structural funds. The new line, financed by the voivodeship self-government and the EU funds, will connect the Gdańsk airport with the centres of Gdańsk and Gdynia, and will open new connections to the nearby towns of Zukowo and Kartuzy, which will further integrate suburban centres with the core of the agglomeration. The 55-km long PKM will have 18 stops (10 in Gdańsk and 6 in Gdynia) in 2015.

The long process of creating a single public transport system was facilitated by the Gdańsk Bay Metropolitan Board, initiated by the head of the voivodeship in 2003. Four years later the Gdańsk Bay Inter-Communal Transport Union was established, and since 2009 it has coordinated the metropolitan public transport system connecting eight towns (Gdańsk, Gdynia, Pruszcz Gdański, Reda, Rumia, Sopot, and Wejherowo) and seven rural municipalities (Kolbudy, Kosakowo, Luzino, Pruszcz Gdański, Wejherowo, Żukowo, and Szemud). The Union offers daily and monthly tickets for all modes of public trans-

\footnotetext{
Since 2012, the Western Ring Road.
} 
port, including urban trains, buses, trams and trolleybuses, operated by the state-owned SKM and municipal transport companies of Gdańsk, Gdynia and Wejherowo.

The Gdańsk Lech Wałęsa International Airport can be a successful example of joint metropolitan infrastructure initiatives. Located $12 \mathrm{~km}$ west-northwest of the Gdańsk centre, $10 \mathrm{~km}$ from Sopot and $23 \mathrm{~km}$ from Gdynia, this third largest airport in Poland serves ca. 3 million passengers per year (2013). It is owned by the voivodeship self-government $(31.45 \%)$, the City of Gdańsk $(29.45 \%)$, the City of Gdynia (1.14\%), the City of Sopot $(0.35 \%)$, and the Airports State Company $(37.61 \%)$. Another example of coordination of a metropolitan transport system is Tristar - an integrated smart metropolitan traffic management system. The project, initiated by the Technical University of Gdańsk and begun in 2006, has been supported by $€ 156$ million from the EU (ca. 85\% of the total cost). The goal is to shorten the time of car travel on major roads by $20 \%$ by a smart use of cameras, sensors, interactive road signs, and so on. The system is currently being introduced to the main transport axis, and is scheduled to be completed by the end of 2014 .

\section{Metropolitan hopes, or cooperation and functional integration}

After more than 80 years of both spontaneous and forced amalgamation, the Gdańsk metropolitan area has become a reasonably integrated urban region. Gdańsk, Gdynia, Sopot and the surrounding suburbs create a cohesive system based on mass commuting across the entire polycentric region. The administrative borders are usually barely visible, sometimes only in the form of sizeable welcome boards, an abruptly changing quality of bike paths, or different styles of Christmas street decorations. Functional unity and physical proximity demand inter-city cooperation in many aspects. Current arrangements include state and regional entities, such as energy and gas providers, or environmentally protected urban forests. Economic partnership and common labour, property, retail and wholesale markets, together with financial and banking services as well as secondary and higher education, work in a single, metropolitan operational milieu. Local universities, research and IT centres, in particular the dominant University of Gdańsk, have their campuses scattered across different locations in the three cities. There is also practically one real-estate market, and commonly used health-care and leisure facilities. One of the best examples of intra-metropolitan cooperation is the construction and management of a Gdańsk-Sopot joint venture: the Ergo Arena (or Hala Gdańsk-Sopot). The boundary between the two cities - Sopot and Gdańsk - runs through the very middle of this multi-purpose indoor arena, opened in 2010, designed to host up to 15,000 visitors.

The regional integration discourse has been facilitated by some of the key local and regional actors, including investors, researchers and some politicians (Sagan, Canowiecki 2011). A distinctive role is played here by the active and effective local media, including two major newspapers, four radio stations, regional television, and a very popular Web portal www.trójmiasto. pl. Since all the media draw on the same sources and offer one edition and programme for the whole of the metropolis ${ }^{6}$, they contribute to the fostering of metropolitan integration within the region. In 2005 the newspapers Gazeta Wyborcza and Dziennik Battycki as well as the state-owned Radio Gdańsk and the Gdańsk $3^{\text {rd }}$ TV Channel organised public debates, meetings and programmes promoting cooperation in the city region. In 2006 the local edition of Gazeta Wyborcza initiated the "I love my city" competition as well as a Tri-City survey. In that pragmatically oriented assessment, the inhabitants of the region opted for a single network ticket for the region as the main priority. Also the local Dziennik Battycki organised a "Let's keep together" forum and debate to promote the idea of metropolitan cooperation (Szczepuła 2006). In 2013 local television began a series of programmes under the umbrella of "We in the Metropolis" (My w Metropolii). Local NGOs have been very active in the Gdańsk

6 In the early 2000s Dziennik Baltycki had different local editions for Gdańsk and Gdynia. After a few months the readers clearly showed their disapproval of the disintegration of information, which was followed by a sales decrease. Soon after a single Tri-City edition was re-introduced. 
arena. Some of them, like the Lepsze Miasto (Better City) Foundation, try to play a key social role in the process of metropolitan integration. Other examples of somewhat enforced but most effective collaboration imposed by EU and national policies include the integration of tourism promotion and the Tri-City Agglomeration Air Protection Programme.

There have also been more and more joint trans-metropolitan social and cultural projects inspired by the media and local mangers of culture. In the early 2007 the biggest regional newspaper Gazeta Wyborcza Trójmiasto organised a Przystanek Trójmiasto (Tri-City Bus Stop) forum, where vital problems of metropolitan development were discussed and analysed. More than 8,000 people signed the Tri-City Card as a declaration of closer municipal cooperation with the metropolis. In March 2007 the declaration of cooperation, inspired and facilitated by Gazeta Wyborcza, was signed by the mayors of Gdańsk, Gdynia and Sopot, and by the President of the voivodeship government. During the whole of 2007, every Saturday the question "What next with the Tri-City metropolis?" returned on the local pages of the newspaper. In December 2007 a new cultural initiative was initiated to integrate the cultural life of the metropolis. Larry Ugwu, director of the Baltic Cultural Centre in Gdańsk, organised a Metropolitan Festival of Culture under the title 'Metropolia jest Okey' (the Metropolis is $\mathrm{OK}$ ) in three clubs in Gdańsk, Gdynia and Sopot. 33 local artists, performers and musicians participated in this first integrated cultural event. The 2013 (sixth) edition gathered more than 50 musicians in seven clubs around the metropolitan area and seemed to prove the merger of the milieu, at least cultural, of the urban region.

\section{Metropolitan fears or competition and complementary functions}

The evolution of self-governance in the Gdańsk area which followed the first post-communist free local election of 1990 had been highly uneven across different municipalities. In the early 1990s, Gdynia, governed by Franciszka Cegielska, a dynamic 'iron lady mayor', became a national model of a successfully transformed society and municipality, known for its vibrant and entrepreneurial milieu. Gdańsk was then torn by social and economic problems of incompetence and corruption in local government. Competition, conspiracy, as well as a certain level of aggressive rivalry developed between the cities; and the underlying virtual divisions became much more 'real' in operational terms. The historical and deeply rooted anti-Gdańsk fears in Gdynia came to be a significant part of urban identity, transmitted to another generation of Gdynia inhabitants and enhanced by very effective local and national Gdynia PR. The different historical backgrounds, visible in the cities' different architectural appearances, are often used as symbols of differences between them.

The role of personalities and individual actors is not to be underestimated. In general, it is not institutional arrangements or structures that allow collaboration to emerge, but it is the personal charisma and policy-making ability of individual key actors that can facilitate collaborative arrangements, with or without support by formal structures. Since the late 1990s, the management of and relations between Gdańsk and Gdynia have been changing. The current mayor of Gdańsk, Paweł Adamowicz, in office since 1998, has been able to implement many sustainable economic and infrastructural programmes, including business support systems, a technology centre, parks and sporting facilities, and a bike paths scheme, in addition to many road construction and mega-projects, like the infrastructure for the EURO 2012 European Football Championship. Gdańsk and its elites are also important linking actors, at the national and international scales. Since 2007, the Gdańsk mayor has been president of the Union of Polish Metropolises; he is also member of a number of international bodies, including the EU Assembly of Regional and Local Representatives. Presently, Gdańsk is considered one of the most efficient applicants in Poland for EU structural funds. Gdynia's development, regardless of some economic successes, seems to have lost its earlier 'drive'. Sopot, much smaller than the other two cities, makes much of its image at the national level as an upmarket leisure and entertainment centre. This has translated into one of the highest property prices in Central Europe. 
Presently, in general public opinion, the mayor of Gdynia is regarded as the main obstacle to the idea of closer and formalised inter-metropolitan collaboration ${ }^{7}$ (Szczepuła 2006).

The competition concentrates in fields controlled or facilitated by the rival municipalities. Three local development strategies, although based on practically the same regional strengths and values, accentuate local differences and particularities. The strategies are followed by separate communal organisations, unemployment and environmental policies, entrepreneurship support systems, place marketing and municipally assisted investment, such as sports arenas or road construction. Gdańsk and Gdynia have also different, complementary and somehow competing port authorities, two of the largest container terminals on the Baltic, and competing ferry operators and links to Sweden. There are two major technology and business parks in Gdańsk and Gdynia, and science museums. Cultural and sporting events and festivals are hardly coordinated and often compete with each other. Gdynia, together with Sopot and other smaller suburban municipalities, has established the Chylonka Valley Municipal Union to manage the heat, waste, water, and sewage systems. Gdańsk utilities, by contrast, are largely privatised and managed by foreign firms. Each of the major municipalities has also its own unemployment and entrepreneurship policies, as well as separate chambers of commerce. The competition is additionally facilitated by rival football clubs: Lechia Gdańsk and Arka Gdynia.

There are many examples of inter-metropolitan de-synchronisation, and many of them seem to be connected with Gdynia's individuality. In 2013 the municipality of Gdynia organised its summer book-reading festival at the very same weekend that Sopot organises its literature festival. The construction of the Northern Bypass was accompanied by a hostile dispute between Gdynia and the neighbouring poviats. Probably the most visible recent illustration of the inter-

\footnotetext{
The mayor of Gdańsk compared a metropolis to a 'grand symphonic orchestra'. An influential local journalist, Barbara Szczepuła, followed the metaphor and called Paweł Adamowicz of Gdańsk 'the first fiddle', while Wojciech Szczurek of Gdynia - 'the solo player' (Szczepuła 2006).
}

nal competition, separatism and local ambitions is the Gdynia Kosakowo airport. A navy airfield has been reconstructed to serve civil and cargo traffic, only $25 \mathrm{~km}$ from the expanding Gdańsk Lech Wałęsa airport. The airport has not been opened, the European Commission having decided that the public financial assistance of $€ 22$ million for the Kosakowo airport was illegal (Szczerba, Naskręt, 2013). The airport has to return the money, which means immediate bankruptcy of the almost ready-to-use enterprise with a new terminal and a modernised runway. Shortly before the negative decision was publicised, the mayor of Gdynia published an open letter accusing the EU of an anti-Polish policy. The possible takeover negotiations by the Gdańsk Lech Wałęsa airport in the autumn of 2013 were broken by the mayor of Gdynia's premature statement, sent in the early phase of negotiations to the European Commission, declaring an alleged comprehensive solution of the problem.

One of the major problems of cooperation seems to lie beyond infrastructure and current economic activities, and to involve local identities. Gdynia, historically built as a Polish answer to the German Gdańsk, has for decades constructed its urban narration on anti-Gdańsk distinctiveness and identity (Sagan, Canowiecki, 2011). And even now, the historical reference to Gdynia ${ }^{8}$ described as the 'Polish window to the world' and the fastest growing city, just like in the 1930s - seems to be stronger than in the 1000-year-old Gdańsk (Czepczyński, Górlikowski 2014). The strong Gdynia identity is reflected in very high support for the local administration and residential satisfaction. In a 2013 survey organised by the Polish daily Gazeta Wyborcza, Gdynia inhabitants estimated their quality of life as the highest in Poland (5.38 points), while the satisfaction in Gdańsk reached an average of 4.77 (Sandecki 2013). Strong contentment is linked with local pride and a feeling of self-importance, considera-

8 The historical reference to the quintessentially antiGdańsk local identity of Gdynia was the basis of the author's thesis in a local, broadly discussed newspaper article (Czepczyński, Górlikowski 2014). Counterarguments included mostly historical statements (Gdynia would be much bigger than Gdańsk if the WW2 began 20 years later, or if Gdynia had been made the capital of the voivodeship in 1945). 
bly stronger in Gdynia than in Gdańsk or Sopot. Gdynia's uniqueness, explicit urban milieu and identity are usually confronted with the supposed economic stagnation of Gdańsk. The biggest local media - the Web portals trojmiasto.pl and trojmiasto.gazeta.pl - despite the unity in the name, additionally enhance local separateness on anonymous discussion forums, where the anti-Gdańsk and anti-Gdynia hateful comments reach their climax while increasing the number of Web visitors. It seems that despite the various levels of differences, including social, economic, infrastructural and historical ones, identity is the primary challenging and challenged restraint limiting the integration of the Gdansk metropolitan area. Emotions, fears, past splendours and current prides have fed metropolitan discourse for the last 20 years, while local leaders play the identity card to prove their efficiency and competence.

\section{Towards a Gdańsk Bay Metroplex}

Urban regionalism in post-socialist Central Europe faces a variety of challenges and obstacles. The transition from centrally planned and ruled voivodeships towards self-governed and locally managed regions has been a long and arduous way. Often, lessons are learned 'on the job', from mistakes and lost opportunities. Traditional hierarchical cooperation and governance are supplemented by emerging horizontal and/ or regional structures based on partnership and, often, compromise. The process of horizontal partnership in the form of regionalisation does not come easily or smoothly. Resistance against hierarchies and smaller centres' fears of losing sovereignty often dominate over practical considerations and the obvious need for neighbourly cooperation in the interest of more effective policy making. The interaction between these formal, technocratic forms, and less technocratic, more flexible means of regionalisation is a crucial factor here as a route to regional development (Herrschel, Newman 2005: 220).

The process of metropolitan cooperation has accelerated since 2011. The EU regional policy and the perspective of the future funding programmes supporting trans-municipal projects have resulted in a national and regional policy shift in Poland. The government is working on a new urban law and new metropolitan top-down structures to match the new Integrated Regional Operational Programme scheme, while many large cities prepare their own bottom-up solutions under the auspices of the Union of Polish Metropolises. The national debate found the recent acceleration in regional activities to formalise inter-metropolitan cooperation.

The metropolitanisation of the Tri-City area was formalised on 15 September 2011 when the Gdańsk Metropolitan Area Association (Gdański Obszar Metropolitalny, or GOM) was established. The GOM is a legal association of 47 local communes and poviats inhabited by ca. 1.2 million people and occupying an area of $6,605 \mathrm{~km}^{2}$ (Stowarzyszenie GOM, 2014). Its main goal is to coordinate local and regional development, share the best practices, and enhance the development potential of the area. The association was initiated by Paweł Adamowicz, mayor of Gdańsk, who invited local leaders for a debate on the form and scale of possible cooperation. Major projects implemented by the GOM and benefiting most members of the organisation include the Metropolitan Job Fair and the Metropolitan Investment Offer, Smarter City Exploration, the Social Economy Support Centre, and joint electricity bids.

Two days before the GOM founding meeting the mayor of Gdynia gathered a group of 15 municipal leaders of the northern part of the agglomeration and introduced the NORDA Mayors Forum (Forum Wójtów, Burmistrzów i Prezydentów NORDA), renamed the Metropolitan Mayors' Forum NORDA in 2012. The Forum ${ }^{9}$ is an informal assembly of 22 mayors ${ }^{10}$, focused around five working groups: education, business and tourism promotion, energy, and waste management. Recent actions have mostly been lim-

\footnotetext{
The NORDA uses Gdynia local government's name of the agglomeration, consequently calling the sub-region 'Tri-City Metropolitan Area', while Gdańsk can only appear as the name of the nearby Bay of Gdańsk.

10 As of January 2014 (Norda Forum 2014). Some municipalities are both in the GOM and the NORDA, sometimes as a result of local controversies, as in Rumia. A mayor can join the NORDA on his/her own will, while access to the GOM must be accepted by the local council.
} 
ited to joint tourism promotion (Norda Forum 2014).

The actors of the metropolitan discourse include, besides local governments and their agencies, regional and national politicians, major private, locally based investors, and media. While individuals and local leaders play a crucial role in local policies, they are always an emanation of a the local community's aspirations and attitudes when they represent elected bodies. Local communities and their representatives seem to be recently much more open to collaboration and unification in the metropolitan region, but the historically based references and connotations are still important factors which influence metropolitan governance discourse. Over-reactions and reservations interrelate with contemporary market-driven forces and neo-liberal obstacles. This is a challenging and demanding lesson for both, local societies and the administration. Negotiations and giving up some part of independence come with difficulty, while a drive towards 'Europeanisation' and the necessity to fulfil fiscal requirements push the communities towards unavoidable cooperation at the social, economic and administrative levels.

The latest step towards closer cooperation has practically been enforced by new European financial projects. Integrated Territorial Investments will practically be the main beneficiary of the EU funds aimed to coordinate development investments in 2014-2020. The clear statement by the Ministry of Infrastructure and Development that the Gdańsk area has to create a single Integrated Territorial Investment unit left no hopes for two separate zones. There was controversy concerning the shape of the future unit: the mayor of Gdańsk opted for a new structure based on cooperation between the GOM and NORDA, while the mayor of Gdynia went for individual inter-commune agreements. Negotiations started towards the end of 2013, led by the head of the Voivodeship Office. On 17 January 2014 an agreement was signed, following a compromise on the part of Mayor Adamowicz. The Gdańsk Area Integrated Territorial Investments (or ZIT) consists of 36 communes and poviats (from both the GOM and NORDA) and will be managed by a Gdańsk-based secretary. The organisational structure is based on the ZIT Council consisting of representatives of the local municipalities, universities and NGOs, while operational activities will be managed by the Board of six municipal leaders. All decisions have to be made unanimously or with a $75 \%$ majority of votes (Szczerba 2014). The ZIT procedures create a set of tools for comprehensive metropolitan cooperation, but threats of separatism and hostile activities remain very real.

\section{Conclusions}

Foucault suggests that modern power is a dispersed set of micro-practices, many of which operate through the normalising gaze of surveillance regimes (Dovey 1999). Often, a single influential person, or a network of a few key policy makers, can make a real difference, based on their own beliefs, experience and knowledge. This paper tried to trace a set of decisions and to analyse their consequences. The Gdańsk metropolitan region is a functionally comprehensive area in almost all social, economic and cultural aspects, and as such it represents many aspects of a metropolitan character. The Gdańsk metropolitan area seems to partly meet the other elementary metropolitan feature: the gateway function and external linkages. Its port functions help to facilitate its opening and entry roles, but Gdańsk seems to me more open to national and international linking - not only economic, but also cultural and political. Gdynia seems to be much more focused on its internal, inclusive growth, which can hardly be seen as metropolitan, while Gdańsk activities can be perceived as more focused on its external linkages, international and national relations, and metropolitan growth. Basic disagreements are built upon local identities, enhanced by ambitions and fears of local politicians as well as municipal institutions and initiatives.

The Gdańsk Metropolis, as in many other regions, can be seen as an arena of struggle between integrating and disintegrating forces. Inter-regional cooperation is a learning process facilitated by various local and regional actors. Different conditions, goals, expectations and ambitions create a distinctive network of opportunities and challenges which shape the future of the 
region. The upcoming prospect of virtually and legally disjointed regions depends on the ability of the local communities and, above all, elites, to overcome mental and imagined barriers, and take advantage of possible forms of collaboration - to work out a feasible model of cooperation, respecting and taking advantage of the local differences, and creating a new threesome quality.

\section{References}

Andersson A.E., 2000. Gateway region of the world - an introduction. In: Andersson A.E., Andersson D.E. (eds), Gateways to the global economy. Edward Elgar, Cheltenham: 3-16.

Czepczyński M., 2005. De- vs. re-industrialisation of post-socialist city. The case of Gdańsk. Regions 259: 6-11.

Czepczyński M., 2009. Regionalisation in Gdańsk Area. Virtual disintegration and functional cooperation. International Journal of Public Sector Management 22 (3): 249-259.

Czepczyński M., Górlikowski M., 2014. Wojna gdańsko-gdyńska. "Raj w cieniu większego brata" (Gdańsk vs. Gdynia war. "Paradise in the shadow of the big brother") Online: http:// trojmiasto.gazeta.pl/ trojmiasto/ 1,35636,15253818,Wojna_gdansko_gdynska_Raj_w_cieniu_wiekszego_brata_.html (accessed 13 January 2014).

Davoudi S., 2005. The northern way: A polycentric megalopolism. Yorkshire and Humberside Regional Review 15 (1): 2-4

Dovey K., 1999. Framing places. Mediating power in built form. Routledge, London \& New York.

Herrschel T., Newman P., 2005. Global competition and city regional governance in Europe. In: Sagan I., Halkier H. (eds), Regionalism contested. Institution, society, governance. Ashgate, Aldershot: 203-222.

Johansson J.K., 1997. Global marketing: Foreign entry, local marketing, and global management. Irwin/McGraw-Hill, Boston.
Judge E., Czepczyński M., Wyszomirski O., 2005. Aspects of the development of sustainable transport policies in the Gdańsk Agglomeration. In: Markowski T. (ed.), Regional Scientists' tribute to Professor Ryszard Domański. Polish Academy of Sciences, Warsaw: 322-345.

Klaesson J., Johansson B., Karlsson Ch., 2013. Introduction. In: Klaesson J., Johansson B., Karlsson Ch. (eds), Metropolitan regions: Knowledge infrastructures of the global economy. Springer, Heidelberg, New York, Dortrecht, London.

Knox P.L., Pinch S., 2006. Urban social geography. Pearson, Harlow.

Norda Forum, 2014. Online: http:// nordaforum.pl/ aktualnosci.html (accessed 30 January 2014).

Sagan I., Canowiecki Z., 2011. Między integracją a konkurencją. Gdańsko-Gdyński Obszar Metropolitalny (Between integration and competition. The Gdańsk - Gdynia Metropolitan Area). Scholar, Warszawa

Sandecki M., 2013. Gdynianie zakochani w mieście (Gdynia inhabitants in love with their city). Online: http:// trojmiasto.gazeta.pl/ trojmiasto/ 1,35636,15034485,Gdynianie_zakochani_w_miescie_Prawie_wszystko_oceniaja. html (accessed 30 January 2014).

Stowarzyszenie GOM, 2014. Online: http:/ /www.metropoliagdansk.pl/stowarzyszenie-gom/ (accessed 10 January 2014).

Szczepuła B., 2006. Symfonia metropolitalna (Metropolitan symphony). Dziennik Battycki 151 (30 June 2006): 16.

Szczerba P., 2014. Jest porozumienie Gdańska i Gdyni (There is an agreement between Gdańsk and Gdynia). Online: http:/ / www.trojmiasto.pl/wiadomosci/Jest-porozumienie-Gdanska-i-Gdyni-Dostaniemy-na-inwestycje820-mln-zl-n76215.html (accessed 30 January 2014).

Szczerba P., Naskręt M., 2013. Lotnisko w Kosakowie ma poważne problemy (Kosakowo airport in serious trouble). Online: http://www.trojmiasto.pl/wiadomosci/ Lotnisko- w- Kosakowie- ma- powazne- problemy-Lotniskow-Rebiechowie-rozpoczyna-rozbudowe-n70503.html (accessed 30 January 2014).

Weltrowski P., 2014. Spadła liczba pasażerów SKM (Decrease in the number of SKM passengers). Online: http:// www.trojmiasto.pl/ wiadomosci/ Spadla-liczba-pasazerow-SKM-Winne-remonty-n76587.html (accessed 30 January 2014). 